\title{
Organizational identification as a mediator for the effects of psychological contract breaches on organizational citizenship behavior: Insights from the perspective of ethnic minority employees
}

\author{
Pinar Tufan ${ }^{a,}$, Hein Wendt ${ }^{\mathrm{b}, \mathrm{c}}$ \\ a University of Liège, Belgium \\ ${ }^{\mathrm{b}}$ Korn Ferry Institute, Amsterdam, the Netherlands \\ ${ }^{\mathrm{c}} \mathrm{KU}$ Leuven, Belgium
}

\section{A R T I C L E I N F O}

\section{Article history:}

Received 8 November 2018

Received in revised form

1 July 2019

Accepted 5 July 2019

Available online $\mathrm{xxx}$

\section{Keywords:}

Ethnic minority employees

Transactional

Relational

Balanced and diversity-related

psychological contract breaches

Organizational identification

Organizational citizenship behavior

\begin{abstract}
A B S T R A C T
This study examines the contribution of the psychological contract (PC) framework to the understanding of ethnic minority employees' employment relationships. First, it tests the generalizability of PC types (transactional, relational, and balanced) observed in the general population to ethnic minority employees. Then, to further address the unique needs and motivators of minority employees, this study considers diversity-related PCs. It adopts social exchange theory to explain how transactional, relational, balanced, and diversity-related PC breaches predict organizational citizenship behavior (OCB). Moreover, it draws insights from social identity theory and examines the mediating role of organizational identification in the relationship between types of PC breach and OCB. Data from 361 Turkish employees working as ethnic minorities in Belgium indicate that relational and diversity-related PC breaches predict OCB partially via organizational identification while transactional and balanced PC breaches directly affect OCB.
\end{abstract}

(c) 2019 Elsevier Ltd. All rights reserved.

\section{Introduction}

Maintaining a positive employment relationship is becoming more challenging for organizations considering the current trend in population changes, particularly in countries with immigrant and ethnic minority population (Ashikali \& Groeneveld, 2015). This current study examines ethnic minority employees' employment relationships within psychological contract (PC) framework. A PC provides distinct insights into the changing nature of employment relationships by replacing collective arrangements with individual deals (Guest \& Conway, 2003).

Additional value comes from studying multiple types of PCs and their unique qualities (Montes \& Irving, 2008). In this study, we begin with Rousseau's (1995) PC typology. Based on social exchange theory, we first investigate how transactional, relational, and balanced PC breaches, if not satisfactorily fulfilled by the

\footnotetext{
* Corresponding author.

E-mail addresses: ptufan@uliege.be (P. Tufan), Hein.Wendt@KornFerry.com (H. Wendt).
}

organization (termed PC breach), distinctly affect organizational citizenship behavior (OCB). For further insights, given that workplace diversity motivates a concern with identities and identification processes (Albert, Ashford, \& Dutton, 2000), we refer to social identity theory and propose organizational identification as a mediator of the relationships between transactional, relational, and balanced PC breaches and OCB.

Recent PC literature suggests considering new PCs for specific employees with unique needs and motivators (Cunningham, Barbee, \& Mandal, 2009; Rousseau, 2004). Therefore, as our final step, we turn to diversity-related PCs, which represent promises that respect diversity and influence minority employees' perceptions with regard to their employment relationships (ChrobotMason, 2003). We examine the separate but simultaneous effects of unfulfilled transactional, relational, balanced, and diversityrelated PC (termed PC breach) on ethnic minority employees' organizational identification and, hence $\mathrm{OCB}$.

This study has several contributions to the literature. First, it is the first study to examine minority employees' (e.g., ethnic) PCs with its multiple types. The study focuses on transactional, relational, and balanced PC breaches and tests the applicability of these 
PC types observed in the general population (Rousseau, 2000) to ethnic minorities. The study also focuses on a diversity-related PC breach, which has been neglected but is an increasingly important breach type (Buttner, Lowe, \& Billings-Harris, 2010).

Second, this study focuses on the mediating role of organizational identification in the relationship between PC breaches and OCB. By doing so, it attempts to demonstrate how organizations maintain a superordinate organizational identity (Gaertner \& Dovidio, 2000) to integrate social identity groups, who have been deeply divided in society, (Chrobot-Mason, Ruderman, Weber, Ohlott, \& Dalton, 2007), which, in turn, contributes to organizational performance (i.e., increased $\mathrm{OCB}$ ).

Third, the study targets ethnic minority employees of immigrant origin. Research on immigrants is increasing but remains unsystematic and operationally difficult (Yakushko, 2009). Moreover, contrary to prior workplace diversity research, which is mostly USbased (Hicks-Clarke \& Iles, 2000), this research is conducted in a European country. This is relevant because Europe has been addressing the challenges of increased cultural and ethnic diversity due to recent high immigration rates (Dancygier, 2010).

\section{Literature review and hypotheses development}

\subsection{Transactional, relational, and balanced psychological contract breaches}

Based on social exchange theory, PC consists of a set of beliefs concerning the exchange terms and conditions between the employee and the employing organization (Guest, 2004; Rousseau, 1995). Employees hold different types of PCs with their employers (Montes \& Irving, 2008; Raja, Johns, \& Ntalianis, 2004). Rousseau (1995, 2000) developed the most widely-accepted PC typology. According to Rousseau (2000), PCs vary along the time frame dimensions and performance terms, which leads to four main types of PCs: transactional, relational, balanced, and transitional.

Transactional PCs refer to short duration, monetary, or economic terms and conditions in their reciprocal exchange agreement with employers (Rousseau, 1990). Relational PCs, in contrast, are longterm employment arrangements and include socio-emotional exchanges, mutual trust, and loyalty often in the form of job security. Balanced PCs are simultaneously based on socio-emotional and economic terms and conditions (Rousseau, 2000). In a balanced PC, an employer's long-term commitment to provide continuous training and development results in employees developing skills and performing new and more demanding goals to help the organization become and remain competitive. Transitional PCs are excluded from our study because they are too specific to organizations that are in transition.

There is no study that directly measures transactional, relational, and balanced PCs for ethnic minority employees. Based on the review of the relevant literature, we consider transactional PCs to constitute an important part of the employment relationships of ethnic minority employees for whom the employer relationship is predominantly reliant on economic inducements (Vertommen \& Martens, 2006). In other words, wage differences across countries, as being the number one reason for international labor mobility (see Kerr \& Kerr, 2011), explain why ethnic minorities, who settle in a foreign country for work, most likely have the primary motivation of realizing economic benefits (Oğuz, 2011), and therefore, may highly value the elements of transactional PCs.

For relational and balanced PCs, they are most relevant for majority employees (see Hui \& Graen, 1997; Hui, Lee, \& Rousseau, 2004; Lee, Tinsley, \& Chen, 2000). Previous studies demonstrated that majority employees, compared to their ethnic minority counterparts, are offered a greater number of benefits, which go beyond monetary rewards (Shoobridge, 2006). Such possible differences in majority and minority employees urge us to examine the PC experiences of minority employees (ethnic minorities), which have been neglected in the literature.

A PC breach occurs when an organization fails to fulfill one or more promises in employment relationships (Zhao, Wayne, Glibkowski, \& Bravo, 2007). Ethnic minority employees' PCs, which are expected to be limited in duration, size and scope when not satisfactorily fulfilled by the organization, most likely lead to negative work outcomes. Ethnic minority employees may perceive breaches as evidence of systematic adverse organizational treatment, which influence their work outcomes (e.g., Heslin, Bell, Fletcher, \& Feldman, 2012), particularly reduce their contributions to the success of the organization (Mamman, Kamoche, \& Bakuwa, 2012; Shore et al., 2011). In this study, we investigate how transactional, relational and balanced types of PC breaches undermine ethnic minority employees' contributions in terms of OCBs.

\subsection{Transactional, relational, and balanced psychological contract breaches and organizational citizenship behavior}

OCB is a widely documented consequence of a PC breach (Conway \& Coyle-Shapiro, 2012). OCB shows to what extent employees are willing to contribute to organizations in ways that go beyond the performance requirements of their jobs (Organ, 1988). Like PC theory, OCB is firmly rooted in social exchange theory. Therefore, most previous studies adopt social exchange principles to explain the negative association between employee perceptions of a PC breach and OCB (see meta-analysis of Zhao et al., 2007). Similarly, we suggest that ethnic minority employees' initial response to a PC breach is to reduce OCB before considering, for example, leaving the organization or reducing in-role behaviors, both of which may jeopardize their employability (see Mamman et al., 2012). Notably, such employees cannot risk losing their current employment because of the additional impediments they face in becoming (re)employed (Heslin et al., 2012).

Previous research demonstrated that socio-emotional employment exchanges are more related to OCB than economic employment exchanges (Hui et al., 2004; Organ, 1988). Therefore, an unfulfilled relational PC, which represents unfair socio-emotional exchange is expected to have more impact on ethnic minority employees' OCB compared to a balanced breach, which contains unfulfilled promises of a socio-emotional and economic nature. A transactional PC breach, on the other hand, is expected to have the least effect on such employees' OCB because such a PC is more of an economic exchange. However, we suggest that transactional, relational, and balanced PC breaches have a relationship with ethnic minority employees' OCB to some extent because any mutual understanding between parties, if not achieved satisfactorily, creates some degree of reluctance to cooperate (see Malhotra \& Murnighan, 2002).

Hypothesis 1. The negative effects of relational PC breaches and balanced $\mathrm{PC}$ breaches on OCB are stronger than the negative effects of transactional PC breaches on OCB.

\subsection{Organizational identification mediates the relationship between psychological contract breaches and organizational citizenship behavior}

Organizational identification is defined as the perception of oneness or belongingness to some human aggregate (Ashforth \& Mael, 1989). When employees identify strongly with their organization, they fulfill their needs for affection, belongingness, and 
affiliation (Haslam, Powell, \& Turner, 2000; Johnson \& Ashforth, 2008; Mayhew, Gardner, \& Ashkanasy, 2010). In an increasingly diverse work environment, organizational identification leads to an alignment of perspectives such that employees with diverse backgrounds feel that they are working with rather than against each other (Van Dick \& Haslam, 2012).

Workplace diversity nevertheless challenges organizational identification by causing social categorization processes to occur more frequently (Richard, Barnett, Dwyer, \& Chadwick, 2004). For instance, ethnic minority employees often display a relative identification preference toward members who belong to the same ethnic group that reinforce or are similar to existing perceptions of themselves to achieve self-continuity (Goldberg, Riordan, \& Schaffer, 2010). On the other hand, as suggested by the dual identity approach (Haslam, 2001), once ethnic minority employees successfully maintain their ethnic identification within their organizations, they display willingness for organizational identification for the purpose of self-enhancement (Cooper \& Thatcher, 2010).

Organizations make various efforts to encourage employees to adopt a level of categorization in which all subgroups are encompassed under a shared identity, such as organizational identification (Haslam, Eggins, \& Reynolds, 2003). A PC fulfillment is an important driver of employee organizational identification (Rodwell, Ellershaw, \& Flower, 2015). Breaches, on the other hand, reduce organizational identification by eroding the foundations of the employment relationship (Robinson, 1996). Masterson and Stamper (2003) and Stamper, Masterson, and Knapp (2009) conceptually developed a perceived organizational membership framework, which suggested that a PC breach weakens employees' perceptions of organizational membership as it is associated with their perception of unfulfilled needs. Epitropaki (2013) empirically confirmed Masterson and colleagues' (2003, 2009) perceived organizational membership framework. Other correlational studies by Kreiner and Ashfort (2004); Gibney, Zagenczyk, Fuller, Hester, and Caner (2011); and Zagenczyk, Gibney, Few, and Scott (2011) also demonstrated the negative relationship between a breach and organizational identification.

By drawing insights from the group value model, Restubog, Hornsey, Bordia, and Esposo (2008) investigated how distinctly transactional and relational PC breaches are related to organizational identification. The group value model, drawn from social identity theory, argued that a group leader's treatment matters to people because it communicates symbolic messages about their position within a valued group, which shapes their self-concept and self-definition in terms of that group (Lind \& Tyler, 1988; Tyler, 1989; Tyler \& Lind, 1992). According to Restubog et al. (2008), the group value model might be more useful in explaining responses to a breach when these symbolic concerns are heightened; for example, when the nature of the contract breach is relational rather than transactional.

A transactional PC breach, involving monetary or economic terms and conditions, has limited effect on organizational identification (Restubog et al., 2008). On the other hand, according to Restubog et al. (2008), a relational PC breach, by containing socioemotional elements, communicates symbolic messages about the negative standing of an employee within the organization, which in turn, hinders organizational identification. In the case of ethnic minority employees, personal identity-relevant symbolic messages communicated through a relational PC breach may also become ethnic identity-relevant. In other words, as a function of their ethnic identity, these employees may appraise such a breach as an ethnic identity threat (Smith \& Mackie, 2015; Tufan, Witte, \& Wendt, 2017). Mamman et al. (2012) argued that a threat to their salient social identity causes minority employees to experience deprivation through loss of self-esteem resulting in high dissonance and separation and, consequently, loss of organizational identification (Haslam \& Ellemers, 2005; Kreiner \& Ashfort, 2004).

In addition to Restubog et al.'s (2008) reasoning based on the group value model, Rousseau's (2000) time frame dimension of PCs may be used to explain the separate but simultaneous effect of transactional, relational, and balanced PC breaches on ethnic minority employees' organizational identification. According to Rousseau (2000), PCs vary along the time frame dimensions. We suggest that breaches of long-term relational and balanced PCs, compared to a transactional PC, are more relevant to organizational identification since the experience of group attachment depends on an individual's status as a member of the group but also on the expectation of remaining with the group (Wiesenfeld \& Brockner, 1998).

Organizational identification is a key predictor of important work-related attitudinal and behavioral outcomes including OCB (Cornelissen, 2006; Riketta, 2005; Van Dick, 2001). According to Kane, Magnusen, and Perrewé (2012), highly identified employees will be those who carry out additional role behaviors, not because they are required to but because their self-concept is deeply rooted in the success of the organization.

Previous research documented the mediating role of organizational identification in the relationship between an organizational treatment (e.g., a PC breach) and employee behaviors (e.g., Blader \& Tyler, 2009; Lam, Liu, \& Loi, 2016; Restubog et al., 2008; Tyler \& Blader, 2003). From the perspective of ethnic minority employees, we propose that the mediating role of organizational identification in the relationship between a PC breach and OCB is stronger when a PC contains more long-term and socio-emotional elements (i.e., relational and balanced $\mathrm{PC}$ ) than short-term and economic elements (i.e., transactional PC). Thus, we hypothesize the following:

Hypothesis 2. The effect of PC breach on OCB via organizational identification is stronger for relational and balanced PC breaches than for transactional breaches.

\subsection{Diversity-related psychological contract breach}

Rousseau's typology (1995) of transactional, relational, and balance PC offers a solid base for understanding ethnic minority employees' employment relationship. However, it may fall short of addressing all facets of this discrete association. Previous research suggested that the evolving work environment requires considering "new" and "unique" PCs for diverse employees (Cunningham et al., 2009; Rousseau, 2004). Accordingly, for ethnic minority employees, we focus on diversity-related PCs. More specifically, we investigate how a diversity-related PC breach, in conjunction with transactional, relational, and balanced PC breaches, predicts ethnic minority employees' organizational identification, and hence OCB.

A diversity-related PC can be defined as the sum of a minority employee's beliefs about the diversity-related promises (i.e., supporting the unique issues for minority employees) an organization makes in return for his/her contributions. Previous research demonstrated that minority employees value diversity-related PC promises as highly as other PC promises (Chrobot-Mason, 2003). A diversity-related PC breach occurs when minority employees believe their organization fails to fulfill its diversity-related PC promises. Despite its critical and increasing importance, scholars have focused less on a diversity-related PC breach (Buttner et al., 2010). The first empirical study in this area was conducted by Chrobot-Mason (2003) and demonstrated that a diversity-related breach is strongly linked to lower organizational commitment, lower job satisfaction, and higher levels of cynicism. Buttner et al. (2010) extended Chrobot-Mason's (2003) work across a wider sample revealing that employee perceptions of a diversity-related 
PC breach led to lower reported organizational commitment and higher turnover intentions. Both Chrobot-Mason (2003) and Buttner et al. (2010) demonstrated that a diversity-related PC breach is distinct from general PC breaches. Similarly, we suggest distinctiveness of a diversity-related PC breach from each of the other PC breach types (e.g., transactional, relational, and balanced).

\subsection{Diversity-related $P C$ breach, organizational identification, and organizational citizenship behavior}

Based on social exchange theory, a diversity-related PC may pinpoint how social-exchange value is fostered between a minority employee and the organization. A diversity-related PC fulfillment creates an inclusive work environment where ethnic minority employees feel that they are treated equally and fairly (Buttner et al., 2010) and, consequently, they most likely engage in behaviors that are beneficial for the organization (e.g., OCB). On the other hand, a diversity-related PC breach is expected to lead to an exclusion pattern in the employment exchange relationships resulting in ethnic minority employees' negative reciprocal behaviors such as OCB withdrawal.

Other previous studies also applied social exchange principles to explain the relationship between an organization's diversity management efforts and minority employees' work outcomes (e.g., Ashikali \& Groeneveld, 2015). However, these studies were criticized for being too narrow to capture all aspects of how and why this particular relationship occurs (Joshi, Liao, \& Roh, 2011; McKay, Avery, \& Morris, 2009). Accordingly, we use social identity theory to further explain the relationship between a diversity-related PC breach and OCB given that diversity and diversity issues create concerns about identities and identification processes (Albert et al., 2000). Specifically, a diversity-related PC breach, which has longterm and socio emotional characteristics, is expected to reduce ethnic minority employees' organizational identification, and hence $\mathrm{OCB}$.

Diversity management goes beyond short-term economic benefits; it represents long-term recognition and appreciation of the unique value of each employee to the organization regardless of the employee's background (Ashikali \& Groeneveld, 2015). Such longterm characteristics of diversity management may designate minority employees as legitimate and long-term organizational members, which enhances these employees' attachment to the organization (see Ricco, 2012). A diversity-related PC breach, by causing ethnic minority employees to question the duration of their employment relationships, is expected to reduce their organizational identification, which, in turn, is expected to hinder their OCB.

Socio-emotional characteristics of diversity management may also link diversity management to ethnic minority employees' organizational identification. When an organization promotes and signals the value of diversity through policies and procedures and incorporates diversity into its core qualities, minority employees' experience supportive, respectful, and acknowledging employment relationships. This, in turn, may lead these employees to form stronger and unified bonds with the organization (Gonzalez \& DeNisi, 2009; Triana \& Garcia, 2009). A diversity-related PC breach, on the other hand, may represent an organization's exclusive diversity approach. It is expected to undermine ethnic minority employees' organizational identification, and hence OCB by posing legitimized, current, and/or potential harm to the value, meanings, or enactment of their ethnic identity.

In all, we suggest that transactional, relational, and balanced PCs along with diversity-related PCs provide a more comprehensive understanding for ethnic minority employees' employment relationships. Specifically, we expect that transactional, relational, balanced, and diversity-related PC breaches reduce ethnic minority employees' OCB to varying extents both directly based on social exchange theory and indirectly through social identity theory such as organizational identification. Social exchange principles most likely explain the relationship between a transactional PC breach and OCB more strongly than identification mechanisms (i.e., organizational identification). On the other hand, diversity-related, relational, and balanced PC breaches, by containing long-term and socio-emotional elements, are expected to have negative effects organizational identification, and hence OCB. Thus, we hypothesize the following:

Hypothesis 3. The effect of PC breach on OCB via organizational identification is stronger for relational, balanced, and diversityrelated PC breaches than for transactional breaches.

\section{Methodology}

\subsection{Diversity context}

Chattopadhyay (2003) divided employees by ethnicity and/or race into majority (e.g., white) and minority employees, and used the term "minority employee" to describe employees who belong to various racial/ethnic categories that are and traditionally have been a minority in the workforce. In line with Chattopadhyay's (2003) definition of the ethnic/racial minority employee, we target Turkish immigrant employees in Europe. Turkish immigrants represent one of the largest immigrant communities, and their degree of integration has important social and economic consequences for Europe (Giglou, d'Haenens, \& Gorp, 2019).

Ethnicity and ethnic identification guide the social cognition and behavior of Turkish immigrants in Europe (Phalet \& Güngör, 2004) and the pattern of their migration history fosters this behavior. Many European countries, following an economic boom period, started importing cheaper labor from other markets, resulting in an ethnically and culturally pluralist European market. By the first half of the 1960s, Turkey became one of the largest labor providers (Oğuz, 2011). Many of these immigrants have settled on a more permanent basis, leading to the creation of a growing and often highly visible ethnic minority community.

Previous researches have documented that there is a silent social categorization between Turkish immigrants and host-country nationals in Europe due to ethnic, religious and cultural differences (see Verkuyten \& Yildiz, 2007) and its undeniable effects on work life (Kloostermanan, 1996). According to Chrobot-Mason et al. (2007), organizations face a unique challenge when members of social identity groups who have been deeply divided in the society come together in the workplace, which requires increased efforts and initiatives of organizations. Within the PC framework, we examine employment experiences of Turkish immigrant employees, who work for majority-dominated and majority-owned organizations in Belgium.

In Belgium, the Turkish community, along with the Moroccan, constitutes the largest immigrant population (Hooghe \& Vroome, 2015). In spite of their numbers and the growth of their community, the Turkish immigrants are historically known for low levels of integration in the Belgian society (Giglou et al., 2019). Their societal position has been much worse than that of the majority: They commonly have a lower educational attainment, and are overrepresented in unemployment and low-wage, blue-collar jobs (Laer \& Janssens, 2011; Martens et al., 2005). According to Phalet (2007), Turkish immigrants in Belgium experience significant ethnic penalties, with serious repercussions on the work environment and labor market, which requires organizational efforts that focus on the needs and expectation of this particular group of employees (Shore et al., 2011). 


\subsection{Organizational context}

We aimed to approach medium-to large-sized ethnically diverse organizations dominated by majority employees (e.g., Berdahl \& Moore, 2006). We contacted 26 organizations, and finally agreed upon eight, which have ethnic minority employee populations of 30-35 percent. Within these organizations, along with the Moroccan, the Turkish community was the largest ethnic minority group (10-15 percent of the total employee population). There were other ethnic groups (e.g., Congolese, Bulgarian, Italian, etc) reflecting the ethnic diversity within the organizations.

The targeted organizations were located in four major Belgian cities and operate in diverse sectors, including construction, mining, cleaning, automotive, transport, and telecommunications. At the end of the two-wave data collection period, there were on average 45 participants per organization $(S D=8)$, ranging from 36 to 63 employees.

\subsection{Procedures}

With the support and leading of HR departments, we reached two to three Turkish employees, who are positioned as natural Turkish community leaders in each of the targeted organizations. These employees supported the organization of the data collection process. This procedure is recommended by Pernice (1994) who argues that one of the important difficulty in researching immigrants from quite different cultural contexts than the Western frame of reference is knowledge and observation of cultural etiquette. According to Pernice, researchers may need to approach a given community's leaders before beginning or proceeding with research within a given immigrant group.

All participants were informed about the purpose of the study, its confidentiality, and were encouraged to participate in the survey within two weeks. Since our sample consisted of mostly blue-collar workers with comparatively few technological skills, we administered paper questionnaires. Data were collected between September 2013 and April 2014. We used a time-lagged design to separate the measures of the independent and dependent variables. Based on both PC literature (e.g., Conway \& Coyle-Shapiro, 2012) and diversity literature (e.g., Binder et al., 2009), a time interval of six months in-between the two waves was chosen. However, for organizational reasons, the period ranged from six to eight months. We created a unique code for each participant, which helped us to collect two-wave data while assuring anonymity and confidentiality.

\subsection{Sample}

Overall, 750 questionnaires were distributed of which 570 (76 percent) were returned. Respondents were invited for the second round of data collection for which 416 questionnaires (73 percent) were completed. The deletion of missing values resulted in a final useable sample of 361 employees (48 percent of those originally invited).

The sample includes Turkish employees who are either immigrants themselves or legal dependents of immigrants. This was verified by enquiring about their country of birth, the country of birth of both parents, and that of all four grandparents (Beirens \& Fontaine, 2011). In terms of immigration status, 27 percent were reported as being first-generation immigrants, 40 percent secondgeneration, 26 percent third-generation, and 7 percent either fourth-generation or higher. Fifty-seven percent of the sample consisted of men. In terms of age, 10 percent of the sample was younger than 25 years old, 38 percent between 25 and 34, 36.8 percent between 35 and 44, 13.6 percent between 45 and 54, and 8 percent older than 55. Finally, 73 percent of our sample comprised blue-collar workers.

\subsection{Measures}

The measures of constructs in the proposed models are described below. From the first wave, data were obtained for control variables, transactional, relational, balanced, and diversityrelated PC breaches (T1) while, from the second wave, data were obtained for organizational identification and OCB (T2).

\subsubsection{Multiple types of psychological contract breach}

We measured transactional, relational, and balanced PC breaches with the 15-item scale developed by Coyle-Shapiro and Conway (2005). Transactional PC breaches were measured with six items, an example being "fair pay for the responsibilities of the job." Relational PC breaches were measured with five items. A sample item is "opportunities to be involved in decisions that affect me." Balanced PC breaches were measured with four items. A sample item is "providing career support and mentoring." To measure diversity-related PC breaches, we used a five-item scale developed by Chrobot-Mason (2003) where a sample item is "minority input is considered at all levels." The internal reliabilities of the scales of transactional, relational, balanced, and diversityrelated PC breaches were good $(\alpha=0.90,0.88,0.85$, and 0.87, respectively).

\subsubsection{Organizational identification}

Organizational identification was measured using Mael and Ashforth's six-item scale (1992). A sample item is: "I view the organization's success as my success." The internal reliability of the scale was good $(\alpha=0.89)$.

\subsubsection{Organizational citizenship behavior $(O C B)$}

OCBs have been categorized and measured in several ways (Podsakoff, Whiting, Podsakoff, \& Blume, 2009). Consistent with previous PC research, we used OCB towards the organization (OCBO) (e.g., Restubog et al., 2008), defined as behavior that benefits the organization in general. We measured OCBO with a 7-item, 5-point scale developed by Williams and Anderson (1991). A sample item is "attendance at work is above the norms." The internal reliability of the scale was good $(\alpha=0.88)$.

\subsubsection{Control variables}

We controlled for age and gender. These parameters were selected because older people who have developed more stable PCs may react differently than younger people to a PC breach (Bal, Langeb, Jansena, \& Veldec, 2008). Men and women may have different reactions to a PC breach (Restubog et al., 2008). The possible gender differences consistent with the "double jeopardy" hypothesis (Berdahl \& Moore, 2006) are of particular interest to this study. For example, men may experience better treatment at work, perceive fewer PC breaches, and find PC breaches to be less bothersome than women find PC breaches.

Moreover, we added the effect of immigration status as a control variable. We identified different dummy variables. The dummy variable, which separated the first generation and the other (second or more) generation Turkish immigrants, was found to have significant relationship with the study variables (i.e., organizational identification) and have included in our analysis (e. g., Carlson, Kacmar, Zivnuska, \& Ferguson, 2015; Dawson, Irving, Sharma, Chirico, \& Marcus, 2014). Notably, previous literature has demonstrated that first generation Turkish immigrants in Europe are significantly different from second and third generation counterparts in their earnings, work experiences and labor market 
performance (Algan, Dustmann, Glitz, \& Manning, 2010; Fertig \& Schurer, 2007; Hammarstedt, 2009; Penninx \& GarcesMascarenas, 2016; Platt, 2014).

Finally, we controlled for occupational status as white and bluecollar because if we do not control for occupational status, it will be impossible to know whether the findings are due to occupational status or minority status.

\section{Analysis and results}

\subsection{Preliminary analyses}

The means, standard deviations, and correlations among the research variables are presented in Table 1.

We used a time-lagged design to investigate the effects of types of psychological contract breaches on organizational identification, and hence OCB. As our data were collected using self-reported measures, findings could be affected by common method variance. Therefore, we assessed the extent to which our results may be affected by common method bias. To check for CMV, we followed Podsakoff, MacKenzie, Lee, and Podsakoff's (2003) recommendations and performed the single method factor approach (p. 896, Table 5, Fig. 3A). By adding a single method factor, all intercepts to the six latent variables were still significant $(\mathrm{p}<.01)$ where the intercepts to the CMV were not significant $(\mathrm{p}>.05)$. The model fit well: $\chi 2(447)=669.462, \mathrm{p}=.000, \mathrm{RMSEA}=0.038, \mathrm{CFI}=0.955$.

\subsection{Hypotheses testing}

We examined the fit of our hypothesized model with SEM techniques using the AMOS software package. SEM has several advantages for the testing of mediation (Cheung \& Lau, 2008). SEM is a better statistical tool for the investigation of latent variables with multiple indicators (Holmbeck, 1997). Controlling for measurement error and, thus, avoiding underestimation of mediation effects allows the analysis of more complex models (Hoyle \& Smith, 1994) and the specification of all relevant paths (Baron \& Kenny, 1986). We used several fit indices to assess model adequacy (Joreskog \& Sorbom, 1993; Klein, 1989; Medsker, Williams, \& Holahan, 1994), namely, chi-square ( $\chi 2)$, difference in chi-square ( $\chi 2$ diff), comparative fit index (CFI), root-mean-square-error of approximation (RMSEA), Akaike's information criterion (AIC), normed fit index (NFI), and Tucker-Lewis index (TLI).

We conducted CFA to verify that transactional, relational, balanced, and diversity-related PC breaches represented four distinct types of PC breaches. As expected, the hypothesized fourfactor model fitted the data well $(\chi 2$ (164) $=300.810$, RMSEA $=0.049, C F I=0.954, T L I=0.947$ ). To further check the distinction of a diversity-related PC breach from other PC breach types, we developed alternative models. First, we combined transactional, relational, balanced, and diversity-related PC breaches and obtained a one-factor model. In the second, third, and fourth alternative models, we combined diversity-related PC breach items respectively with transactional, relational, and balanced PC breach items. Our hypothesized four-factor model demonstrated better fit than each of these alternative models (see Table 2).

The hypothesized partial mediation model was tested following a nested model approach (Holmbeck, 1997) (See Table 3). To test Hypotheses 1 and 2, we started by focusing on transactional, relational, and balanced PC breaches. We developed model A by specifying the direct relationships between transactional, relational, and balanced PC breaches and OCB as well as the indirect relationships between these types of PC breaches and OCB via organizational identification. This partial mediation model (Model A) had a moderately good fit, $\chi 2(334)=610.51 ; \chi 2 / \mathrm{DF}=1.828$; $\mathrm{NFI}=0.865 ; \mathrm{TLI}=0.924 ; \mathrm{CFI}=0.933 ; \mathrm{RMSEA}=0.049 ; \mathrm{AIC}=810.51$, and $\mathrm{ECVI}=2.34$. All predicted paths were significant with two exceptions: the relationships between transactional PC breach and organizational identification and balanced PC breach and organizational identification.

In model B, after removing the non-significant relationships, we specified the direct relationships between transactional, relational, and balanced PC breaches and OCB and the indirect relationship between a relational PC breach and OCB via organizational identification. Model B showed a significant improvement, $\chi 2$ $(336)=621.36 ; \quad \chi \quad 2 / \mathrm{DF}=1.849 ; \quad \mathrm{NFI}=0.862 ; \quad \mathrm{TLI}=0.922 ;$ $\mathrm{CFI}=0.938 ; \mathrm{RMSEA}=0.049 ; \mathrm{AIC}=1028.698$, and $\mathrm{ECVI}=2.36$.

Moreover, we included diversity-related PC to our model (Model C). We specified the direct relationships between transactional, relational, balanced, and diversity-related PC breaches and OCB and the indirect relationship between relational and diversity-related PC breaches and OCB via organizational identification. All predicted paths were significant, and Model $C$ provided a moderate fit

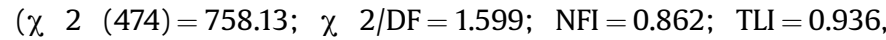
$\mathrm{CFI}=0.943, \quad \mathrm{RMSEA}=0.042 ; \quad \mathrm{AIC}=998.13), \quad$ and $\quad \mathrm{ECVI}=2.88$. Although the improvement in the overall fit between Model B and Model $C$ was not that large, we continued with model $C$ and kept diversity-related PC breach in our model for two reasons. First, as our results indicated, the total effect of a diversity-related PC breach

Table 1

Descriptive Statistics, correlations, and scale reliabilities for variables.

\begin{tabular}{|c|c|c|c|c|c|c|c|c|c|c|c|c|c|}
\hline Variable & M & SD & 1 & 2 & 3 & 4 & 5 & 6 & 7 & 8 & 9 & 10 & 11 \\
\hline 1.Age & 2.56 & .89 & 1 & & & & & & & & & & \\
\hline 2.Gender & .43 & .50 & $-.123^{*}$ & 1 & & & & & & & & & \\
\hline 3.Tenure & 2.05 & .89 & $.571^{* *}$ & -.048 & 1 & & & & & & & & \\
\hline 4.Occupational Status & 1.28 & .45 & $-.247^{* *}$ & $.183^{* *}$ & $-.118^{*}$ & 1 & & & & & & & \\
\hline 5.Immigration Status & .43 & .44 & $.120^{*}$ & -.015 & .080 & $-.348^{* *}$ & 1 & & & & & & \\
\hline 6.Transactional PC breach & -.17 & .90 & .077 & $-.292^{* *}$ & -.001 & -.07 & -.011 & 1 & & & & & \\
\hline 7.Relational PC breach & .32 & .91 & .072 & $-.153^{* *}$ & -.041 & -.081 & -.006 & $.326^{* *}$ & 1 & & & & \\
\hline 8.Balanced PC breach & .34 & .90 & $.162 *$ & $-.255^{* *}$ & .044 & $-.229 * *$ & .050 & $.345^{* *}$ & $.193^{* *}$ & 1 & & & \\
\hline 9. Diversity-related PC breach & .45 & .93 & $.137^{* *}$ & .002 & $.106^{*}$ & -.082 & $.117^{*}$ & $.283^{* *}$ & $.211^{* *}$ & $.212^{* *}$ & 1 & & \\
\hline 10.Organizational identification & 3.29 & 3.29 & .039 & $.163^{* *}$ & .003 & $.154^{* *}$ & $-.145^{* *}$ & $-.184^{* *}$ & $-.245^{* *}$ & $-.141^{* *}$ & $-.22^{* *}$ & 1 & \\
\hline $11 . \mathrm{OCB}$ & 3.44 & 3.44 & $-.132^{*}$ & $.215^{* *}$ & -.067 & $.131^{*}$ & -.103 & $-.294^{* *}$ & $-.344^{* *}$ & $-.250^{* *}$ & -.282 & $.287^{* *}$ & 1 \\
\hline
\end{tabular}

Note: ${ }^{* *} \mathrm{p}<.01,{ }^{*} \mathrm{p}<.05$.

Age (a) was coded as follows: (1) a $\leq 25$, (2) $25<\mathrm{a} \leq 35$, (3) $35<\mathrm{t} \leq 45$, (4) $45<\mathrm{t} \leq 55$, (5) $55+$.

Tenure (y) was coded as follows: (1) $0 \leq \mathrm{y}<=5$, (2) $5<\mathrm{y} \leq 15$, (3) $15<\mathrm{y} \leq 25$, (4) $25<\mathrm{y} \leq 35$, (5) $35+$.

Gender was coded as: (1) Female, (0) Male.

Occupational status was coded as: (1) White-collar, (0) Blue-collar.

Immigration status was coded as: (1) First-generation immigrants, (0) Otherwise. 
Table 2

Confirmatory factor analysis of the psychological contract breach types.

\begin{tabular}{|c|c|c|c|c|c|c|c|c|c|}
\hline & $\chi^{2}$ & (df) & $\chi 2 / \mathrm{df}$ & NFI & TLI & CFI & RMSEA & AIC & ECVI \\
\hline Model A ${ }^{a}$ & 300.81 & 164 & 1834 & 0.905 & 0.947 & 0.954 & 0.049 & 432.81 & 1.247 \\
\hline Model B b & 1696.40 & 170 & 9979 & 0.454 & 0.427 & 0.487 & 0.161 & 1816.40 & 5.235 \\
\hline Model C ${ }^{c}$ & 975.16 & 167 & 5839 & 0.691 & 0.69 & 0.727 & 0.118 & 1104.16 & 3.182 \\
\hline Model D & 849.83 & 167 & 5088 & 0.732 & 0.739 & 0.771 & 0.109 & 975.826 & 2.812 \\
\hline Model E ${ }^{e}$ & 661.91 & 167 & 3964 & 0.791 & 0.811 & 0.834 & 0.092 & 787.913 & 2.271 \\
\hline
\end{tabular}

Notes: ${ }^{* *} p<.001 ; \chi 2=$ chi-square, $\mathrm{df}=$ degrees of freedom; $\mathrm{CFI}=$ comparative fit index.

RMSEA $=$ root mean square of approximation; AIC = Akaike's (1987) information criterion.

$\mathrm{NFI}=$ normed fit index; $\chi 2 \mathrm{diff} / \mathrm{df}=$ relative/normed chi-square; $\mathrm{TLI}=$ Tucker-Lewis index; $\mathrm{CFI}=$ comparative fit index.

${ }^{a}$ Four-factor model (transactional PC breach, relational PC breach, balanced PC breach and diversity-related PC breach),

b One-factor model (combining transactional, relational, balanced, and diversity-related PC breach items in one factor.

c Three-factor model (combining transactional and diversity-related PC breach items in one factor, relational PC breach and balanced PC breach).

d Three-factor model (combining relational and diversity-related PC breach items in one factor, transactional PC breach and balanced PC breach).

e Three-factor model (combining balanced and diversity-related PC breach items in one factor, transactional PC breach, and relational PC breach).

Table 3

Fit statistics from measurement model comparison.

\begin{tabular}{llllllllll}
\hline & $\chi 2$ & $(\mathrm{df})$ & $\chi 2 / \mathrm{df}$ & NFI & TLI & CFI & RMSEA & AIC & ECVI \\
\hline Model A $^{\mathrm{a}}$ & 610.51 & 334 & 1.828 & .865 & .924 & .933 & .049 & 810.51 & 2.34 \\
Model B $^{\mathrm{b}}$ & 621.36 & 336 & 1.849 & .862 & .922 & .931 & .049 & 817.36 & 2.36 \\
Model C $^{\mathrm{c}}$ & 758.13 & 474 & 1.599 & .862 & .936 & .943 & .042 & 998.13 & 2.88 \\
Model D $^{\mathrm{d}}$ & 1061.97 & 604 & 1.758 & .818 & .896 & .911 & .047 & 1333.97 & 3.84 \\
Model E $^{\mathrm{e}}$ & 846.82 & 506 & 1.709 & .848 & .925 & .932 & .044 & 1092.82 & 3.15 \\
\hline
\end{tabular}

Notes: ${ }^{* *} p<.001 ; \chi 2=$ chi-square, $\mathrm{df}=$ degrees of freedom; $\mathrm{CFI}=$ comparative fit index.

RMSEA = root mean square of approximation; AIC = Akaike's (1987) information criterion.

$\mathrm{NFI}=$ normed fit index; $\chi 2 \mathrm{diff} / \mathrm{df}=$ relative/normed chi-square; $\mathrm{TLI}=$ Tucker-Lewis index; $\mathrm{CFI}=$ comparative fit index.

a Partial mediation (transactional PC breach, relational PC breach and balanced PC breach).

b Partial mediation (relational PC breach and diversity-related PC breach), direct (transactional PC breach and balanced PC breach).

${ }^{c}$ Partial mediation (relational PC breach and diversity-related PC breach), direct (transactional PC breach and balanced PC breach).

d Partial mediation (relational PC breach and diversity-related PC breach), direct (transactional PC breach and balanced PC breach) and control variables.

e Partial mediation (relational PC breach and diversity-related PC breach), direct (transactional PC breach and balanced PC breach) and gender.

on OCB was the second largest (following relational PC breach) among PC breach types. The total effect of a transactional PC breach on OCB is 0.171 ; a relational PC breach on OCB is 0.305 ; a balanced PC breach on OCB is 0.123 , and a diversity-related PC breach on OCB is 0.194 . Second, the proposed mediating effect of organizational identification in the relationship between breaches and OCB exits only when the breaches are relational and diversity-related, which empirically provides powerful insights into ethnic minority employees' inclusion patterns at work.

We developed Model D by modifying Model C to specify additional paths from control variables (age, immigration status, gender, and blue/white collar status) to OCB. The results indicated that age, immigration status, and blue/white collar status were not significantly related to the study variables, and Model D did not provide any significant improvement in the overall fit (Model C vs.

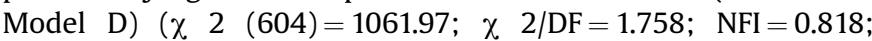
$\mathrm{TLI}=0.896 ; \quad \mathrm{CFI}=0.911 ; \quad \mathrm{RMSEA}=0.047 ; \quad \mathrm{AIC}=1333.97, \quad$ and $\mathrm{ECVI}=3.84)$. Because there were no substantive changes in the results of the hypothesized predictions, we excluded insignificant control variables from our final model.

Based on the results, in our final model (Model E), we modified Model $\mathrm{C}$ by specifying an additional path from gender as a control variable. We chose Model E as our final model, which shows an acceptable fit: $\chi 2(506)=846.82 ; \chi 2 / \mathrm{DF}=1.709 ; \mathrm{NFI}=0.848$; $\mathrm{TLI}=0.925 ; \quad \mathrm{CFI}=0.932 ; \quad \mathrm{RMSEA}=0.044 ; \quad \mathrm{AIC}=1092.82, \quad$ and $\mathrm{ECVI}=3.15$.

Model E partially confirmed our hypotheses (see Fig. 1). In line with Hypothesis 1 and 3, transactional, relational, balanced, and diversity-related PC breaches have a direct relationship with OCB. Model E provided partial support for Hypothesis 2 and 3: Organizational identification mediates the relationships between relational and diversity-related PC breaches and OCB, but not the relationships between transactional and balanced PC breaches and OCB.

Finally, to estimate the standard errors and the confidence intervals of the indirect effects of relational and diversity-related PC breaches on OCB via organizational identification, we performed bootstrap (1500 samples and 95 percent bootstrap confidence intervals) (MacKinnon, Lockwood, \& Williams, 2004). Bootstrap results confirmed the mediating role of organizational identification in the relationship between a relational PC breach and $\mathrm{OCB}(\mathrm{CI}$ : $.021, .090)$, and a diversity-related PC breach and OCB (CI: 0.014 , 0.073) (see Tables 4 and 5).

\section{Discussion}

This study serves five main purposes. From the perspective of ethnic minority employees, first, it investigates the distinct effect of transactional, relational, and balanced PC breaches on OCB. Second, this study examines the mediating role of organizational identification in the relationship between transactional, relational, and balanced PC breaches and OCB. Third, it explores whether a diversity-related PC breach is a distinct construct. Fourth, it considers diversity-related PC breach as a unique PC breach type and investigates the effect of a diversity-related PC breach in conjunction with other PC breach types on organizational identification, and hence OCB. Finally, it evaluates the contributions of a diversityrelated PC breach in ethnic minority employees' employment relationships.

This study is the first to examine minority employees' (i.e., ethnic minorities) PCs with its multiple types. Contrary to most of the existing PC studies, which are limited to transactional and relational PCs, this study focuses on the neglected PC types: balanced and diversity-related. Balanced and diversity-related PCs are increasingly important in contemporary market conditions characterized by factors such as diversity, boundarylessness, and protean careers (Baruch, 2006; Buttner et al., 2010).

All the confirmed negative relationships between transactional, relational, balanced, and diversity-related PC breaches and OCB from the perspective of ethnic minority employees mirror the 


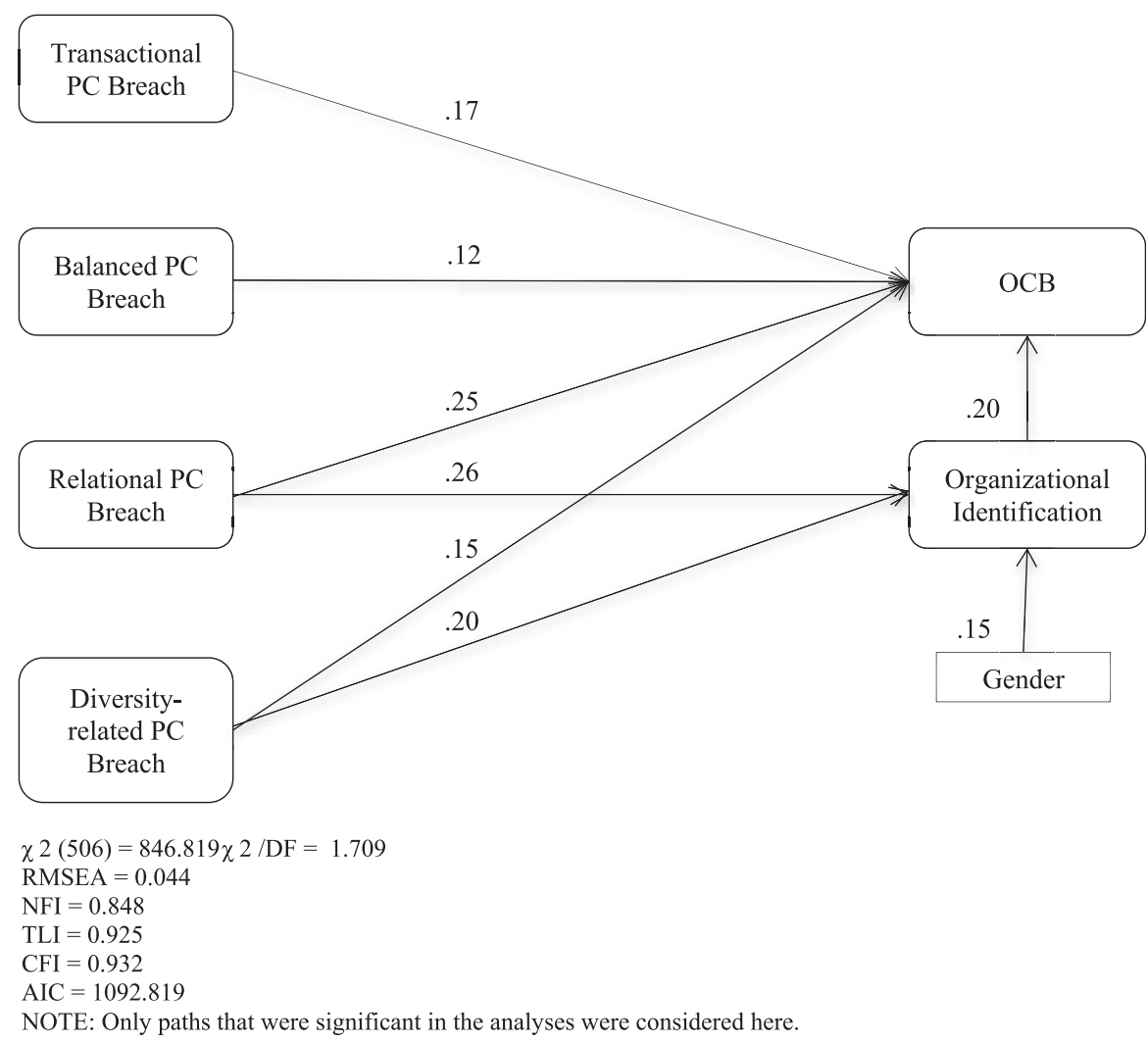

Fig. 1. Hypothesized relationships among PC breach types, organizational identification, and OCB.

Table 4

Direct and indirect effects of relational PC breach on OCB.

\begin{tabular}{lllll}
\hline & Standardized effect & SE & $P$ & $\frac{95 \% \mathrm{CI}}{\text { (bias corrected) }}$ \\
\hline Total effect & 0.305 & & & .179 .432 \\
Direct effect & 0.262 & 0.069 & 0.002 & .128 .383 \\
Indirect effect & 0.052 & 0.069 & 0.002 & .021 .090 \\
\hline
\end{tabular}

Table 5

Direct and indirect effects of diversity-related PC breach on OCB.

\begin{tabular}{lllll}
\hline & Standardized effect & SE & $P$ & $\frac{95 \% \mathrm{CI}}{\text { (bias corrected) }}$ \\
\hline Total effect & 0.194 & & & .098 .289 \\
Direct effect & 0.153 & 0.057 & 0.003 & .018 \\
Indirect effect & 0.04 & 0.06 & 0.018 & .054 .250 \\
\hline
\end{tabular}

arguments of prior studies on general employees. These prior studies documented the explanatory capacity of social exchange principles in the relationship between breach and OCB (see Zhao et al., 2007 for a meta-analysis).

One of the main suggestions of this study is that a PC with longterm duration and a socio-emotional nature, when breached, results in a greater decrease in ethnic minority employees' organizational identification. This argument, which relies on Restubog et al.'s (2008) group value model-based reasoning and also our assumptions drawn from Rousseau's time frame dimension of PCs, finds partial support in our results. In line with our hypotheses, the results indicated that both relational and diversity-related PC breaches have a significant negative relationship with ethnic minority employees' organizational identification. Given that minorities have a strong tendency of attributing particularly negative events, outcomes, and situations to their minority identity (Yzerbyt \& Demoulin, 2010), ethnic minority employees appraise relational and diversity-related PC breaches as devaluation of their ethnic identity within the organization, which hinders their identification with the organization. These findings support the dual identity approach (Haslam, 2001). That is, organizations can promote minority employees' organizational identification only when they acknowledge and value their significant social identities (e.g., ethnic identity), which can be maintained through fulfillment of relational and diversity-related PCs.

Contrary to our hypothesis, transactional, and balanced PC breaches are not found to have (significant) effect on organizational identification. In fact, we do not expect a large significant effect of a transactional PC breach on organizational identification since transactional PCs include monetary and economic terms and conditions. However, lack of a significant effect of a balanced PC breach on organizational identification is surprising given that a balanced PC has long-term time frame, contains some socio-emotional elements, and maintains many of the positive features of a relational contract (McInnis, Meyer, \& Feldman, 2009). A balanced PC supports ethnic minority employees in their pursuit of skills and knowledge essential for long-term organizational success. This, in turn, increases employees' employability for long periods and, accordingly, is expected to foster their attachment to their organizations. However, fulfillment of such a PC was not found to translate into organizational identification.

Many factors can explain the lack of significant effect of a balanced PC breach/fulfillment on organizational identification. For instance, given that a balanced PC is related to employees' training, development and career progress, its fulfillment helps employees 
achieve career success and self-directed goals (Rowold, 2007). When employees develop skills that are both firm-specific and valuable to the broader labor market, their transferability increases; they become more visible to the external labor market rendering an exit easier (Gardner, 2005). According to $\mathrm{Ng}$ and Feldman (2012), the more employees perceive themselves as highly marketable and employable, the more they may consider better deals in elsewhere, which may override their attachment to their current employer.

Another reason could be that our sample is ethnic minority employee-specific. According to Shoobridge (2006), career opportunities, training, and growth, which are the core elements of a balanced PC, are offered to majority employees more than ethnic minority employees. Ethnic minority employees, who have limited expectations about balanced PC promises, react less than majority employees to balanced PC breaches in terms of organizational identification (James, 1993).

The results concerning the mediating role of organizational identification showed that the association between breaches and OCB could be understood to varying extents through self-definition and self-categorization and/or in terms of exchange and reciprocity, depending on the type of PC breach. For instance, transactional and balanced PC breaches are related to lower OCB of ethnic minority employees, which can be explained through social exchange principles. Relational and diversity-related PC breaches, on the other hand, reduce ethnic minority employees' OCB by damaging their employment relationships as do transactional and balanced PC breaches, but they also cause these employees to dissociate their identity from that of the organization.

Finally, through our findings, we conclude that Rousseau's (2000) PC typology, which consists of transactional, relational, and balanced PCs, is compatible and well-established. Therefore, it applies to a wide variety of employee groups including ethnic minorities to understand their employment relationships. As our results show, there are also benefits to studying a diversity-related PC breach along with other PC breach types. First, a diversity-related PC breach is a distinct construct from other PC breach types. Second, the total effect of a diversity-related PC breach on ethnic minority employees' OCB was found to be the second largest among all PC breach types following a relational PC breach. Moreover, the mediating role of organizational identification in the relationship between PC breaches and OCB exists only when the breaches are relational and diversity-related since such breaches communicate both personal and ethnic identity-relevant information. Notably, the ethnic identity-relevant information communicated through breach, if breach is not overtly diversity-related (e.g., relational PC breach), could be only a subtle cue suggesting that a minority employee receives treatment discrimination within the organization simply because of social identity group membership. On the other hand, a diversity-related breach undoubtedly indicates devaluation or ignorance of an ethnic identity, which undermines ethnic minority employees' organizational identification and, hence, their contributions in terms of OCB. As accentuated by Ferguson and Porter (2013), an organization's mismanaged diversity efforts can be blamed for increased social categorizations, which interfere with the organization's overall functioning.

\subsection{Limitations}

Overall, the theoretical contributions of this study should be viewed considering several limitations. One major limitation of our research stems from its being limited to Turkish employees. This hinders the generalizability of our results to other immigrant populations in Europe/rest of the world, and also prevents us making valuable comparisons among ethnic minority groups. For instance, Turkish individuals are highly collectivist (Hofstede, 1980), and collectivism is a relevant cross-cultural variable that influences how employees respond to favorable and unfavorable organizational treatments such as compared to individualists, collectivists have more tolerance for breach/violations (Erdogan \& Liden, 2006).

Second, this study is situated within the Belgian context, which may also pose generalizability constraints to other countries/cultures. Belgian culture is, for example, characterized by a strong security orientation (Hofstede, Hofstede, \& Minkov, 2010). Accordingly, a relational PC fulfillment may be particularly important as it contains promises regarding job security. Moreover, during the data collection period (November 2013), Belgium faced an economic crisis, which negatively influenced Belgian organizations' employment policy particularly for minority employees (Gsir, Lafleur, \& Stanek, 2016). However, given that EU countries maintain a relatively generous level of social security and labor standards compared to other parts of the world (e.g., the United States), employees in EU countries are relatively more protected during times of economic crisis.

Another limitation of this study is in the measurement and operationalization of OCB. We collect OCB as performance data via self-report questionnaires, raising concerns about common method bias. However, recent research by Carpenter et al. (Ellis, 2007) provides strong evidence supporting the use and construct-related validity of self-rated OCB. Moreover, we limit ourselves to only OCB towards the organization as our operationalization of OCB. As such, the use of one dimension may not completely capture the OCB construct. However, previous studies adopted the same approach, but did not consider it as a serious limitation (Carpenter, Berry, \& Houston, 2014). In contrast, they chose it purposely due to the stronger connection between PC breach/fulfillment and OCB towards the organization (Restubog \& Bordia, 2006; Restubog, Bordia, \& Tang, 2006; Restubog et al., 2008).

Finally, there are also other factors of individual (i.e., xenophobia, essentialism beliefs and lack of openness), cultural (i.e., cultural superiority, collectivism/individualism and power distance), and organizational (i.e., diversity climate, psychological safety, supervisor status and role) natures, which may influence the findings of this study and thus deserve to be considered. For instance, according to Singh, Winkel, and Selvarajan (2013), the presence of a psychologically safe work environment within the organization encourages minority employees to feel confident in expressing their true selves, without fear of being judged as inferior or incompetent.

\subsection{Practical implications and conclusion}

Because of high immigration rates, European organizations have become ethnically and culturally pluralist. Therefore, organizational authorities give priority to maintaining high-quality employment relationships with ethnic minority employees. Organizational authorities have given increased attention and allocated more resources to fulfill such employees' unique needs and motivations (Yang \& Konrad, 2011).

A PC, with its flexibility, ease of customization, and ease of implementation, may support organizations in regulating their relationships with ethnic minority employees and to be more proactive in reaping the benefits of diversity. Through making and fulfilling right combination of PC promises, organizational authorities attract and retain minority employees (e.g., ethnic minorities), promote inclusion of these employees to the organization, and demonstrate that diversity is a core part of the organization and is perpetually and unconditionally valued (see Richard \& Johnson, 2001). On the other hand, similar to other poorly executed 
diversity management efforts, which is an even worse situation than undertaking no efforts (Chrobot-Mason, 2003), PC breaches have important damaging effects on ethnic minority employees' work outcomes.

Organizations engage in transactional, relational, balanced, and diversity-related PCs with their ethnic minority employees, all of which, when not satisfactorily fulfilled by the organization, may cause these employees' OCB withdrawal. Organizations should note that OCB becomes increasingly important in the survival of organizations because organizations rely more on employees to fill the gap between what they are specifically rewarded for and the emergent behaviors necessary for the organization to remain competitive (Dekas, Bauer, Welle, \& Kurkoski, 2013).

Organizations should be aware that some types of PC breaches could markedly reduce ethnic minority employees' OCB by damaging exchange relationships and by eroding self-definition. Relational (such as care, respect, loyalty) and diversity-related (such as equality, fairness, identity recognition) PC breaches are such types. These PC breaches may communicate and/or recall the information that ethnic minority employees are devalued and hold marginalized positions within organizations mostly because of their ethnic background, which cause these employees to disassociate from the organization, and hence to reduce their $\mathrm{OCB}$ engagement.

Overall, this study guides organizations in fulfilling PCs. Particularly for relational and diversity-related PCs, although their fulfillment is relatively more difficult for organizations in contemporary market conditions, they should not be overlooked. Through fulfillment of relational and diversity-related PCs, organizations can encourage ethnic minority employees to maintain their ethnicity before locating it within the context of a binding superordinate identity - organizational identification (see also Hornsey \& Hogg, 2000). This allows the goals of the organization and those of these employees to become increasingly integrated and congruent. It may seem odd to speak of identification in a time of turbulence and uncertainty. However, it is precisely because individuals seek situated moorings in each of their social domains that it is important to understand the potential contributions of identification in today's organizations (Ashforth, Harrison, \& Corley, 2008).

\section{References}

Albert, S., Ashford, B., \& Dutton, J. (2000). Organizational identity and identification: Charting new waters and building new bridges. Academy of Management Review, 25(1), 13-17.

Algan, Y., Dustmann, C., Glitz, A., \& Manning, A. (2010). The economic situation of first and second-generation immigrants in France, Germany and the United Kingdom. Economic Journal, 120(542), F4-F30.

Ashforth, B. E., Harrison, S. H., \& Corley, K. G. (2008). Identifications in organizations: An examination of four fundamental questions. Journal of Management, 34(3), 325-374.

Ashforth, B. E., \& Mael, F. (1989). Social identity theory and the organization. Academy of Management Review, 14(1), 20-39.

Ashikali, T., \& Groeneveld, S. (2015). Diversity management for all? An empirical analysis of diversity management outcomes across groups. Personnel Review, 44(5), 757-780.

Bal, P. M., Langeb, A. H. D., Jansena, P. G. W., \& Veldec, M. E. G. V. D. (2008). Psychological contract breach and job attitudes: A meta-analysis of age as a moderator. Journal of Vocational Behavior, 72(1), 143-158.

Baron, R. M., \& Kenny, D. A. (1986). The moderator-mediator variable distinction in social psychological research: Conceptual, strategic and statistical considerations. Journal of Personality and Social Psychology, 51, 1173-1182.

Baruch, Y. (2006). Career development in organizations and beyond: Balancing traditional and contemporary viewpoints. Human Resource Management Review, $16,125-138$.

Beirens, K., \& Fontaine, J. R. J. (2011). Somatic and emotional well-being among Turkish immigrants in Belgium: Acculturation or culture? Journal of CrossCultural Psychology, 42(1), 56-74.

Berdahl, J. L., \& Moore, C. (2006). Workplace harassment: Double jeopardy for minority women. Journal of Applied Psychology, 91, 426-436.

Binder, J., Brown, R., Zagefka, H., Funke, F., Kessler, T., Mummendey, A., \& Leyens, J. P. (2009). Does contact reduce prejudice or does prejudice reduce contact? A longitudinal test of the contact hypothesis among majority and minority groups in three European countries. Journal of Personality and Social Psychology, 96(4), $843-856$.

Blader, S. L., \& Tyler, T. R. (2009). Testing and extending the group engagement model: Linkages between social identity, procedural justice, economic outcomes, and extrarole behavior. Journal of Applied Psychology, 94(2), 445-464.

Buttner, E. H., Lowe, K. B., \& Billings-Harris, L. (2010). The impact of diversity promise fulfillment on professionals of color outcomes in the USA. Journal of Business Ethics, 91, 501-518.

Carlson, D. S., Kacmar, K. M., Zivnuska, S., \& Ferguson, M. (2015). Do the benefits of family-to-work transitions come at too great a cost? Journal of Occupational Health Psychology, 20(2), 161-171.

Carpenter, N. C., Berry, C. M., \& Houston, L. (2014). A meta-analytic comparison of self-reported and other-reported organizational citizenship behavior. Journal of Organizational Behavior, 35(4), 547-574.

Chattopadhyay, P. (2003). Can dissimilarity lead to positive outcomes? The influence of open versus closed minds. Journal of Organizational Behavior, 24(3), 295-312.

Cheung, G. W., \& Lau, R. S. (2008). Testing mediation and suppression effects of latent variables, Organizational Research Methods, 11(2), 296-325.

Chrobot-Mason, D. (2003). Keeping the promise: Psychological contract violations for minority employees. Journal of Managerial Psychology, 18(1), 22-36.

Chrobot-Mason, D., Ruderman, M. N., Weber, T. J., Ohlott, P. J., \& Dalton, M. A. (2007). Illuminating a cross-cultural leadership challenge: When identity groups collide. International Journal of Human Resource Management, 18(11) 2011-2036.

Conway, N., \& Coyle-Shapiro, J. A.-M. (2012). The reciprocal relationship between psychological contract fulfilment and employee performance and the moderating role of perceived organizational support and tenure. Journal of Occupational and Organizational Psychology, 85, 277-299.

Cooper, D., \& Thatcher, S. M. B. (2010). Identification in organizations: The role of self-concept orientations and identification motives. Academy of Management Review, 35(4), 516-538.

Cornelissen, J. P (2006). Metaphor and the dynamics of knowledge in organization theory: A case study of the organizational identity metaphor. Journal of Management Studies, 43, 683-709.

Coyle-Shapiro, J. A.-M., \& Conway, N. (2005). Exchange relationships: Examining psychological contracts and perceived organizational support. Journal of Applied Psychology, 90(4), 774-781.

Cunningham, M. R., Barbee, A. P., \& Mandal, E. (2009). Hurt feelings and the work place. In A. L. Vangelisti (Ed.), Feeling hurt in close relationships (pp. 417-456). New York, NY: Cambridge University Press.

Dancygier, R. M. (2010). Immigration and conflict in Europe. Cambridge, MA: Cambridge University Press.

Dawson, A., Irving, P. G., Sharma, P., Chirico, F., \& Marcus, J. (2014). Behavioura outcomes of next-generation family members' commitment to their firm. European Journal of Work \& Organizational Psychology, 23(4), 570-581.

Dekas, K. H., Bauer, T. N., Welle, B., \& Kurkoski, J. (2013), Organizational citizenship behavior, version 2.0: A review and qualitative investigation of OCBs for knowledge workers at google and beyond. Academy of Management Perspectives, 27(3), 219-237.

Ellis, J. B. (2007). Psychological contracts: Does work status affect perceptions of making and keeping promises? Management Communication Quarterly, 20(4) $335-362$.

Epitropaki, O. (2013). A multi-level investigation of psychological contract breach and organizational identification through the lens of perceived organizational membership: Testing a moderated-mediated model. Journal of Organizational Behavior, 34, 65-86.

Erdogan, B., \& Liden, R. C. (2006). Collectivism as a moderator of responses to organizational justice: Implications for leader-member exchange and ingratiation. Journal of Organizational Behavior, 27, 1-17.

Ferguson, M., \& Porter, S. C. (2013). An examination of categorization processes in organizations: The root of intergroup bias and a root to prejudice reduction. In Q. M. Roberson (Ed.), The Oxford handbook of diversity and work (pp. 289-340). NY: Oxford University Press.

Fertig, M., \& Schurer, S. (2007). Labour market outcomes of immigrants in Germany: The importance of heterogeneity and attrition bias. Ruhr Economic Papers, 30.

Gaertner, S. L., \& Dovidio, J. F. (2000). Reducing intergroup bias: The common ingroup identity model. Philadelphia, PA: The Psychology Press.

Gardner, T. M. (2005). Interfirm competition for human resources: Evidence from the software industry. Academy of Management Journal, 48, 237-256.

Gibney, R., Zagenczyk, T. J., Fuller, J. B., Hester, K., \& Caner, T. C. (2011). Exploring organizational obstruction and the expanded model of organizational identification. Journal of Applied Social Psychology, 41, 1083-1109.

Giglou, R. I., d'Haenens, L., \& Gorp, B. V. (2019). Determinants of degree of integration of Turkish diaspora in Belgium, The Netherlands, and Germany. International Communication Gazette, 81, 259-282.

Goldberg, C. B., Riordan, C., \& Schaffer, B. S. (2010). Does social identity theory underlie relational demography? A test of the moderating effects of uncertainty reduction and status enhancement on similarity effects. Human Relations, 63(7), 903-926.

Gonzalez, J. A., \& DeNisi, A. S. (2009). Cross-level effects of demography and diversity climate on organizational attachment and firm effectiveness. Journal of Organizational Behavior, 30(1), 21-40.

Gsir, S., Lafleur, J.-M., \& Stanek, M. (2016). Migration policy reforms in the context of 
economic and political crises: The case of Belgium. Journal of Ethnic and Migration Studies, 42(10), 1651-1669.

Guest, D. E. (2004). The psychology of the employment relationships: An analysis based on the psychological contract. Applied Psychology: International Review, 53(4), 541-555.

Guest, D. E., \& Conway, N. (2003). The psychological contract, health and well-being. In M. J. Schabracq, J. A. M. Winnubst, \& C. L. Cooper (Eds.), International handbook of work and health (pp. 9-24). Oxford, UK: John Wiley \& Sons Ltd.

Hammarstedt, M. (2009). Intergenerational mobility and the earnings position of first-, second-, and third-generation immigrants in Sweden. Kyklos, 62(2), 275-292.

Haslam, S. A. (2001). Psychology in organizations: The social identity approach. London, UK: Sage.

Haslam, S. A., Eggins, R. A., \& Reynolds, K. J. (2003). The ASPIRe model: Actualizing social and personal identity resources to enhance organizational outcomes. Journal of Occupational and Organizational Psychology, 76, 83-113.

Haslam, S. A., \& Ellemers, N. (2005). Social Identity in industrial and organizationa psychology: Concepts, controversies, and contributions. In G. P. Hodgkinson, \& J. K. Ford (Eds.), International review of industrial and organizational psychology (Vol. 20, pp. 39-118). Chichester, UK: John Wiley.

Haslam, S. A., Powell, C., \& Turner, J. C. (2000). Social identity, self categorization and work motivation: Rethinking the contribution of the group to positive and sustainable organizational outcomes. Applied Psychology: International Review, 49, 319-339.

Heslin, P. A., Bell, M. P., Fletcher, P. O., \& Feldman, D. C. (2012). The devil without and within: A conceptual model of social cognitive processes whereby discrimination leads stigmatized minorities to become discouraged workers. Journal of Organizational Behavior, 33(6), 840-862.

Hicks-Clarke, D., \& Iles, P. (2000). Climate for diversity and its effects on career and organisational attitudes and perceptions. Personnel Review, 29(3), 324-345.

Hofstede, G. (1980). Culture's consequences: International differences in work related values. Beverly Hills, CA: Sage.

Hofstede, G., Hofstede, G. J., \& Minkov, M. (2010). Cultures and organizations: Software of the mind ( 3 rd ed.). New York: McGraw-Hill.

Holmbeck, G. N. (1997). Toward terminological, conceptual, and statistical clarity in the study of mediators and moderators: Examples from the child-clinical and pediatric psychology literatures. Journal of Consulting and Clinical Psychology, 65, 599-610.

Hooghe, M., \& Vroome, T. D. (2015). The perception of ethnic diversity and antiimmigrant sentiments: A multilevel analysis of local communities in Belgium. Ethnic and Racial Studies, 38(1), 38-56.

Hornsey, M. J., \& Hogg, M. A. (2000). Assimilation and diversity: An integrative model of subgroup relations. Personality and Social Psychology Review, 4(2), $143-156$.

Hoyle, R. H., \& Smith, G. T. (1994). Formulating clinical research hypotheses as structural equation models: A conceptual overview. Journal of Consulting and Clinical Psychology, 62, 429-440.

Hui, C., \& Graen, G. B. (1997). Guanxi and professional leadership in contemporary Sino-American joint ventures in mainland China. The Leadership Quarterly, 8, $451-465$.

Hui, C. Lee, C. \& Rousseau, D. M. (2004). Psychological contract and organizationa citizenship behavior in China: Investigating generalizability and instrumentality. Journal of Applied Psychology, 89(2), 311-321.

ames, K. (1993). The social context of organizational justice: Cultural, intergroup and structural effects on justice behaviors and perceptions. In R. Cropanzano (Ed.), Justice in the workplace (pp. 21-51). Hillsdale: Lawrence Erlbaum.

Johnson, S. A., \& Ashforth, B. E. (2008). Externalization of employment in a service environment: The role of organizational and customer identification. Journal of Organizational Behavior, 29(3), 287-309.

Joreskog, K. G., \& Sorbom, D. (1993). LISREL 8: Structural equation modeling with the SIMPLIS command language. Chicago Scientific International Software.

Joshi, A., Liao, H., \& Roh, H. (2011). Bridging domains in workplace demography research: A review and reconceptualization. Journal of Management, 37, $521-552$

Kane, R. E., Magnusen, M. J., \& Perrewé, P. L. (2012). Differential effects of identification on extra-role behavior. Career Development International, 17(1), 25-42.

Kerr, S. P., \& Kerr, W. R. (2011). Economic impacts of immigration: A survey. Cambridge, MA: National Bureau of Economic Research.

Klein, H. J. (1989). An integrated control theory model of work motivation. Academy of Management Review, 14, 150-172.

Kloostermanan, R. (1996). Mixed experiences: Post industrial transition and ethnic minorities on the Amsterdam labour market. Journal of Ethnic and Migration Studies, 22(4), 637-653.

Kreiner, G. E., \& Ashfort, B. E. (2004). Evidence toward an expanded model of organizational identification. Journal of Organizational Behavior, 25, 1-27.

Laer, K. V., \& Janssens, M. (2011). Ethnic minority professionals' experiences with subtle discrimination in the workplace. Human Relations, 64(9), 1203-1227.

Lam, L. W., Liu, Y., \& Loi, R. (2016). Looking intra-organizationally for identity cues: Whether perceived organizational support shapes employees' organizational identification. 69(2), 345-367.

Lee, C., Tinsley, C. H., \& Chen, Z. X. (2000). Psychological normative contracts of work group members in the U. S. and Hong Kong. Thousand Oaks, CA: Sage.

Lind, E. A., \& Tyler, T. R. (1988). The social psychology of procedural justice. New York: Plenum.

MacKinnon, D. P., Lockwood, C. M., \& Williams, J. (2004). Confidence limits for the indirect effect: Distribution of the product and resampling methods. Multivariate Behavioral Research, 39(1), 99-128.

Mael, F., \& Ashfort, B. E. (1992). Alumni and their alma mater: A partial test of the reformulated model of organizational identification. Journal of Organizational Behavior, 13, 103-123.

Malhotra, D., \& Murnighan, J. K. (2002). The effects of contracts on interpersonal trust. Administrative Science Quarterly, 47, 534-559.

Mamman, A., Kamoche, K., \& Bakuwa, R. (2012). Diversity, organizational commitment and organizational citizenship behavior: An organizing framework. Human Resource Management Review, 22, 285-302.

Martens, A., Ouali, N., Vertommen, S., Van de maele, M., Dryon, P., \& Verhoeven, H. (2005). Ethnic discrimination on the labor market in Brussels. Research within the Social Pact for employment framework for people who live in Brussels. Retrieved from Brussel/Leuven.

Masterson, S., \& Stamper, C. L. (2003). Perceived organizational membership: An aggregate framework representing the employee-organization relationship. Journal of Organizational Behavior, 24, 473-490.

Mayhew, M. G., Gardner, J., \& Ashkanasy, N. M. (2010). Measuring individuals' need for identification: Scale development and validation. Personality and Individual Differences, 49(5), 356-361.

McInnis, K. J., Meyer, J. P., \& Feldman, S. (2009). Psychological contracts and their implications for commitment: A feature-based approach. Journal of Vocational Behavior, 74, 165-180.

McKay, P. F., Avery, D. R., \& Morris, M. A. (2009). A tale of two climates: Diversity climate from subordinates' and managers' perspectives and their role in store unit sales performance. Personnel Psychology, 62, 767-791.

Medsker, G. J., Williams, L. J., \& Holahan, P. J. (1994). A review of current practices for evaluating causal models in organizational behavior and human resources management research. Journal of Management, 20, 439-464.

Montes, S. D., \& Irving, P. G. (2008). Disentangling the effects of promised and delivered inducements: Relational and transactional contract elements and the mediating role of trust. Journal of Applied Psychology, 93(6), 1367-1381.

Ng, T. W. H., \& Feldman, D. C. (2012). Breaches of past promises, current job alternatives, and promises of future idiosyncratic deals: Three-way interaction effects on organizational commitment. Human Relations, 65(11), 1463-1486.

Organ, D. W. (1988). Organizational citizenship behavior: The good soldiers syndrome. Lexington, MA: Lexington Books.

Oguz, G. (2011). The impact of Turkish labour migration on the human resources in the European Union. In Paper presented at the 7th international strategic management conference, Paris, France.

Penninx, R. \& Garces-Mascarenas, B. (2016). The concept of integration as an analytical tool and as a policy concept. In R. Penninx, \& B. Garces-Mascarenas (Eds.), IMISCOE seriesIntegration processes and policies in Europe: Contexts, levels and actors (pp. 11-29). Springer.

Pernice, R. (1994). Methodological issues in research with refugees and immigrants. Professional Psychology: Research and Practice, 25, 207-213.

Phalet, K. (2007). Down and out: The children of migrant workers in the Belgian labour market. See heath \& cheung 2007. In A. Heath, \& S.-Y. Cheung (Eds.), Unequal chances: Ethnic minorities in western labour markets. Oxford: Oxford University Press, $143-80$.

Phalet, K., \& Güngör, D. (2004). Muslim in The Netherlands: Religious dimensions, ethnic relations and citizenship: Turks and Moroccans in The Netherlands. The Hague, Netherlands: Sociaal Cultureel Planbureau.

Platt, L. (2014). Is there assimilation in minority groups' national, ethnic and religious identity? Ethnic and Racial Studies, 37(1), 46-70.

Podsakoff, P. M., MacKenzie, S. B., Lee, J. Y., \& Podsakoff, N. P. (2003). Common method biases in behavioral research: A critical review of the literature and recommended remedies. Journal of Applied Psychology, 88, 879-903.

Podsakoff, N. P., Whiting, S. W., Podsakoff, P. M., \& Blume, B. D. (2009). Individualand organizational-level consequences of organizational citizenship behaviors: A meta-analysis. Journal of Applied Psychology, 94(1), 122-141.

Raja, U., Johns, G., \& Ntalianis, F. (2004). The impact of personality on psychological contracts. Academy of Management Journal, 47(3), 350-367.

Restubog, S. L. D., \& Bordia, P. (2006). Workplace familism and psychological contract breach in the Philippines. Applied Psychology, 55(4), 563-585.

Restubog, S. L. D., Bordia, P. \& Tang, R. L. (2006). Effects of psychological contract breach on performance of IT employees: The mediating role of affective commitment. Journal of Occupational and Organizational Psychology, 79, $299-306$

Restubog, S. L. D., Hornsey, M. J., Bordia, P., \& Esposo, S. R. (2008). Effects of psychological contract breach on organizational citizenship behaviour: Insights from the group value model Journal of Management Studies, 45(8), 1377-1401.

Ricco, R. (2012). Utilizing a new human relations framework to leverage workforce diversity. In C. L. Scott, \& M. Y. Byrd (Eds.), Handbook of research on workforce diversity in a global society: Technologies and concepts. Hershey, PA: IGI Global.

Richard, O. C., Barnett, T., Dwyer, S., \& Chadwick, K. (2004). Cultural diversity in management, firm performance, and the moderating role of entrepreneurial orientation. Academy of Management Journal, 47, 255-266.

Richard, O. C., \& Johnson, N. B. (2001). Understanding the impact of human resource diversity practices on firm performance. Journal of Managerial Issues, 13(2), $177-195$.

Riketta, M. (2005). Organizational identification: A meta-analysis. Journal of Vocational Behavior, 66, 358-384.

Robinson, S. L. (1996). Trust and breach of psychological contract. Administrative Science Quarterly, 41, 574-599. 
Rodwell, J., Ellershaw, J., \& Flower, R. (2015). Fulfill psychological contract promises to manage in-demand employees. Personnel Review, 44(5), 689-701.

Rousseau, D. M. (1990). New hire perceptions of their own and their employer's obligations: A study of psychological contracts. Journal of Organizational Behavior, 11, 389-400.

Rousseau, D. M. (1995). Psychological contracts in organizations: Understanding written and unwritten agreements. Thousand Oaks, CA: Sage.

Rousseau, D. M. (2000). Psychological contract inventory (Tech. Rep. No. 2000-02) (Retrieved from Pittsburgh, PA).

Rousseau, D. M. (2004). Psychological contracts in the workplace: Understanding the ties that motivate. The Academy of Management Executive, 18(1), 120-127.

Rowold, J. (2007). The effect of career exploration on subsequent training performance. Human Resource Development International, 10(1), 43-58.

Shoobridge, G. E. (2006). Multi-ethnic workforce and business performance: Review and synthesis of the empirical literature. Human Resource Development Review, 5(1), 92-137.

Shore, L. M., Randel, A. E., Chung, B. G., Dean, M. A., Ehrhart, K. H., \& Singh, G. (2011). Inclusion and diversity in work groups: A review and model for future research. Journal of Management, 37, 1262-1289.

Singh, B., Winkel, D. E., \& Selvarajan, T. T. (2013). Managing diversity at work: Does psychological safety hold the key to racial differences in employee performance? Journal of Occupational and Organizational Psychology, 86, 242-263.

Smith, E. R., \& Mackie, D. M. (2015). Dynamics of group-based emotions: Insights from intergroup emotions theory. Emotion Review, 7(4), 349-354.

Stamper, C. L., Masterson, S., \& Knapp, J. (2009). A typology of organizational membership: Understanding different membership relationships through the lens of social exchange. Management and Organization Review, 5, 303-328.

Triana, M. D. C., \& Garcia, M. F. (2009). Valuing diversity: A group value approach to understanding the importance of organizational efforts to support diversity. Journal of Organizational Behavior, 30, 941-962.

Tufan, P., Witte, K. D., \& Wendt, H. J. (2017). Diversity-related psychological contract breach and employee work behavior: Insights from intergroup emotions theory. International Journal of Human Resource Management, 1-25.

Tyler, T. R. (1989). The psychology of procedural justice: A test of the group-value model'. Personality and Social Psychology, 57, 830-838.

Tyler, T. R., \& Blader, S. L. (2003). The group engagement model: Procedural justice, social identity theory, and cooperative behaviors. Personality and Social
Psychology Review, 7, 349-361.

Tyler, T. R., \& Lind, E. A. (1992). A relational model of authority in groups. In M. Zanna (Ed.), Advances in experimental social psychology (Vol. 25, pp. 115-191). New York: Academic Press.

Van Dick, R. (2001). Identification in organizational contexts: Linking theory and research from social and organization psychology. International Journal of Management Reviews, 3, 265-283.

Van Dick, R., \& Haslam, S. A. (2012). Stress and well-being in the workplace: Support for key propositions from the social identity approach. In J. Jetten, C. Haslam, \& S. A. Haslam (Eds.), The social cure: Identity, health, and well-being (pp. 175-194). New York Psychology Press.

Verkuyten, M., \& Yildiz, A. A. (2007). National (dis)identification and ethnic and religious identity: A study among Turkish-Dutch muslims. Personality and Social Psychology Bulletin, 33, 1448-1462.

Vertommen, S., \& Martens, A. (2006). Ethnic minorities rewarded: Ethnostratification on the wage market in Belgium.

Wiesenfeld, B. M., \& Brockner, J. (1998). Toward a psychology of contingent work. In J. J. Halpern, \& R. C. Stern (Eds.), Debating rationality - nonrational aspects of organizational decision making. Cornell University Press.

Williams, L. J., \& Anderson, S. E. (1991). Job satisfaction and organizational commitment as predictors of organizational citizenship behavior and in-role behaviors. Journal of Management, 17(3), 601-617.

Yakushko, O. (2009). Xenophobia: Understanding the roots and consequences of negative attitudes toward immigrants. The Counseling Psychologist, 37(1) 36-66.

Yang, Y., \& Konrad, A. M. (2011). Understanding diversity management practices: Implications of institutional theory and resource-based theory. Group \& Organization Management, 36(1), 6-38.

Yzerbyt, V. Y., \& Demoulin, S. (2010). Intergroup relations. In S. T. Fiske, D. T. Gilbert, \& G. Lindzey (Eds.), Handbook of social psychology (Vol. 2, pp. 1024-1083). Hoboken: NJ Wiley.

Zagenczyk, T. J., Gibney, R., Few, W. T., \& Scott, K. L. (2011). Psychological contracts and organizational identification: The mediating effect of perceived organizational support. Journal of Labor Research, 32(3), 254-281.

Zhao, H., Wayne, S. J., Glibkowski, B. C., \& Bravo, J. (2007). The impact of psychological contract breach on work-related outcomes: A meta-analysis. Personne Psychology, 60, 647-680. 